\title{
Hubungan antara QT Variability Index dan Laju Filtrasi Glomerulus pada Penyakit Ginjal Kronik Predialisis
}

\author{
Sugiantoro, ${ }^{1}$ Augustine Purnomowati, ${ }^{2,3}$ Abdul Hadi Martakusumah, ${ }^{3}$ \\ Chaerul Achmad ${ }^{2}$ \\ ${ }^{1}$ Rumah Sakit Al-Islam Bandung, ${ }^{2}$ Departemen Kardiologi dan Kedokteran Vaskular Fakultas \\ Kedokteran Universitas Padjadjaran-Rumah Sakit Dr. Hasan Sadikin Bandung, ${ }^{3}$ Departemen Ilmu \\ Penyakit Dalam Fakultas Kedokteran Universitas Padjadjaran-Rumah Sakit Dr. Hasan Sadikin \\ Bandung
}

\begin{abstract}
Abstrak
Penderita penyakit ginjal kronik (PGK) mempunyai risiko yang tinggi untuk mengalami aritmia ventrikel dan kematian mendadak (sudden cardiac death/SCD). Angka kejadian SCD pada penderita PGK meningkat seiring dengan menurunnya laju filtrasi glomerulus (glomerular filtration rate/GFR). Mekanisme patofisiologi yang mendasari SCD pada umumnya aritmia ventrikel yang berhubungan dengan ketidakstabilan repolarisasi miokardium. QT variability index (QTVI), suatu indeks yang menggambarkan ketidakstabilan repolarisasi miokardium, merupakan prediktor yang kuat untuk terjadi aritmia fatal dan SCD. Penelitian ini merupakan studi observasi potong lintang untuk menilai hubungan antara QTVI dan GFR pada penderita PGK predialisis dengan GFR $<60 \mathrm{~mL} /$ menit. Penelitian ini dilakukan pada penderita PGK yang berobat ke Poliklinik Ginjal Hipertensi Rumah Sakit Dr. Hasan Sadikin Bandung periode Oktober-Desember 2011. Penelitian ini melibatkan 51 subjek. Pemeriksaan elektrokardiografi (EKG) istirahat dilakukan pada semua subjek dan selanjutnya dilakukan penghitungan QTVI. Hampir semua subjek menderita hipertensi atau mendapat antihipertensi (94\%). Gambaran EKG dengan hipertrofi ventrikel kiri didapatkan pada 37\% subjek dan QTVI rata-rata subjek sebesar 0,16 (SD 0,24). Hubungan antara QTVI dan GFR dianalisis menggunakan Spearman's rank correlation. QT variability index mempunyai hubungan yang bermakna baik dengan GFR $(\mathrm{r}=-0,816 ; \mathrm{p}<0,001)$ maupun dengan estimated glomerular filtration rate $(\mathrm{eGFR})(\mathrm{r}=-0,460 ; \mathrm{p}<0,001)$. Simpulan, terdapat hubungan sangat kuat antara QTVI dan GFR pada penderita PGK predialisis, makin rendah GFR makin panjang nilai QTVI. [MKB. 2012;44(4):193-98].
\end{abstract}

Kata kunci: Kematian jantung mendadak, laju filtrasi glomerulus, penyakit ginjal kronik, QT variability index

\section{Correlation between QT Variability Index and Glomerular Filtration Rate in Predialysis Chronic Kidney Disease}

\begin{abstract}
Chronic kidney disease (CKD) patients are at increased risk for ventricular arrhythmia and sudden cardiac death (SCD). The rate of SCD in CKD patients increased as glomerular filtration rate decreased. Sudden cardiac death is generally mediated by ventricular arrhythmias associated with instability of myocardial repolarization. QT variability index (QTVI) as an index of myocardial repolarization instability is a strong predictor for fatal ventricular arrhythmias and SCD. The aim of this study was to evaluate correlation between QTVI and GFR $(<60$ $\mathrm{mL} / \mathrm{minute}$ ) in predialysis CKD patients. This study was done in Kidney and Hypertension Clinic of Dr. Hasan Sadikin Hospital Bandung, from October to December 2011. A total of 51 subjects were included in this study and had their resting electrocardiography (ECG) recorded and QTVI calculated, 94\% had hypertension or received anti hypertension, while only 37\% fulfilled the ECG criteria for left ventricular hypertrophy. We determined the correlation between QTVI and GFR using Spearman's rank, with mean QTVI 0.16 (SD 0.24), we had strong and significant correlation between QTVI and GFR $(\mathrm{r}=-0.816, \mathrm{p}<0.001)$ and moderate correlation between QTVI and estimated glomerular filtration rate $(\mathrm{r}=-0.460, \mathrm{p}<0.001)$. In conclusions, there is a strong correlation between QTVI and GFR in predialysis CKD patients, the lower GFR the higher QTVI value. [MKB. 2012;44(4):193-98].
\end{abstract}

Key words: Chronic kidney disease, glomerular filtration rate, QT variability index, sudden cardiac death

Korespondensi: Sugiantoro, dr., Sp.JP, Rumah Sakit Al-Islam Bandung, jalan Soekarno Hatta 644 Bandung, mobile 081321595040, e-mail sugi.abizzzz@gmail.com 


\section{Pendahuluan}

Penderita penyakit ginjal kronik (PGK) mengalami stres hemodinamik serta gangguan metabolik yang berat, sehingga berisiko tinggi untuk terjadi kardiomiopati, aterosklerosis, dan arteriosklerosis di kemudian hari. ${ }^{1}$ Konsekuensinya angka kematian kardiovaskular pada penderita PGK jauh lebih tinggi dibandingkan dengan populasi umum. ${ }^{2}$

Kematian kardiovaskular pada penderita PGK dengan estimated glomerular filtration rate (eGFR) $>60 \mathrm{~mL} /$ menit per $1,73 \mathrm{~m}^{2}$ terutama disebabkan aterosklerosis, ${ }^{3}$ sedangkan pada penderita dengan eGFR $<60 \mathrm{~mL} /$ menit $/ 1,73 \mathrm{~m}^{2}$, terutama disebabkan oleh aritmia ventrikel dan gagal jantung. Angka kejadian aritmia ventrikel dan kematian jantung mendadak (sudden cardiac death/SCD) semakin meningkat seiring dengan makin menurunnya laju filtrasi glomerulus, ${ }^{4}$ bahkan sebanyak $60 \%$ kematian kardiovaskular pada penderita PGK yang menjalani dialisis berhubungan dengan SCD. ${ }^{5}$

Mekanisme kematian jantung mendadak pada penderita penyakit ginjal kronik belum diketahui secara pasti, namun diduga berhubungan dengan aritmia ventrikel fatal yang didasari oleh gangguan repolarisasi. ${ }^{6}$ Gangguan repolarisasi ventrikel dapat dinilai melalui rekaman elektrokardiografi (EKG), yaitu pengukuran interval QT, penilaian dinamika gelombang $\mathrm{T}$, pengukuran sudut $\mathrm{spQRS}-\mathrm{T}$, serta dispersi QT, namun sayangnya parameter tersebut bukan prediktor yang kuat untuk menilai kematian akibat aritmia. ${ }^{7}$ Manifestasi gangguan repolarisasi juga dapat dinilai pada osilasi beat-to-beat QT interval. Salah satu parameter untuk menilai adanya variability interval QT yaitu QT variability index (QTVI). ${ }^{8}$ Pemanjangan QTVI telah terbukti menjadi prediktor yang sangat kuat untuk terjadi aritmia fatal dan kematian jantung mendadak. ${ }^{9,10}$

Pada penderita PGK terdapat pemanjangan QTVI yang bermakna bila dibandingkan dengan kontrol sehat. ${ }^{11}$ Angka kejadian aritmia fatal dan kematian jantung mendadak pada penderita PGK meningkat seiring dengan makin rendahnya laju filtrasi glomerulus. ${ }^{4,6} \mathrm{Hal}$ ini mungkin berhubungan dengan QTVI yang makin panjang sebagai salah satu mekanisme yang mendasarinya, namun belum ada penelitian yang dilakukan untuk membuktikan hal tersebut. Penelitian ini bertujuan untuk menilai hubungan antara QTVI dan laju filtrasi glomerulus pada penderita PGK predialisis.

\section{Metode}

Penelitian ini merupakan studi epidemiologi klinik dengan rancangan potong lintang. Subjek penelitian penderita PGK predialisis yang berobat jalan di Poliklinik Ginjal Hipertensi Departemen
Ilmu Penyakit Dalam RSUP Dr. Hasan Sadikin Bandung yang dipilih secara consecutive sampling. Kriteria inklusi penelitian ini adalah laki-laki atau perempuan berusia $>18$ tahun dengan laju filtrasi glomerulus antara 14 dan $60 \mathrm{~mL} /$ menit, sedangkan kriteria eksklusi adalah diabetes melitus, penyakit jantung koroner, fibrilasi atrium, dan subjek yang menggunakan obat antiaritmia kelas I, kelas III atau alat pacu jantung.

Koefisien korelasi (r) yang bermakna secara klinis adalah 0,4 , maka dengan taraf kepercayaan $95 \%\left(Z_{\alpha}=1,64\right)$ dan power penelitian $90 \%\left(Z_{\beta}=1,28\right)$ ukuran sampel yang diperlukan dalam penelitian ini paling sedikit 51 orang.

Analisis statistik yang digunakan adalah untuk menguji adanya korelasi antara QTVI dan laju filtrasi glomerulus. Pearson correlation dipergunakan bila data mempunyai distribusi yang normal, akan tetapi bila distribusi data tidak normal maka dipergunakan Spearman correlation. Analisis statistik dilakukan menggunakan piranti lunak SPSS for Windows versi 18.

Penelitian ini telah mendapat persetujuan dari Komite Etik Penelitian Kesehatan RS Dr. Hasan Sadikin Bandung.

\section{Hasil}

Pada penelitian ini didapatkan 51 subjek yang memenuhi kriteria inklusi serta tidak termasuk kriteria eksklusi.

Nilai tengah kadar kreatinin serum adalah $1,7 \mathrm{mg} / \mathrm{dL}$, sedangkan nilai tengah glomerular filtration rate (GFR) sebesar $34,4 \mathrm{~mL} / \mathrm{menit}$. Subjek dengan nilai GFR 30,00-59,99 mL/menit (penyakit ginjal kronik stadium 3) sebanyak $59 \%$, sedangkan subjek dengan nilai GFR 15,00 $29,99 \mathrm{~mL} / \mathrm{menit}$ (penyakit ginjal kronik stadium 4) sebanyak $41 \%$. Uji normalitas data dilakukan menggunakan metode one sample KolmogorovSmirnov test.

Hasil uji korelasi antara QTVI dan laju filtrasi glomerulus menunjukkan hubungan bermakna baik antara QTVI dan GFR $(\mathrm{r}=-0,816 ; \mathrm{p}<0,001)$ maupun antara QTVI dan eGFR $(\mathrm{r}=-0,460$; $\mathrm{p}<0,001$, namun hubungan antara QTVI dan GFR lebih baik dibandingkan dengan QTVI dan eGFR (Tabel 3).

\section{Pembahasan}

Hampir semua subjek penelitian menderita hipertensi atau mendapat pengobatan antihipertensi yaitu $94 \%$. Hal ini tidak jauh berbeda dengan penelitian sebelumnya. Arinanda ${ }^{12}$ mendapatkan hipertensi pada seluruh subjek penelitiannya 
Tabel 1 Karakteristik Umum Subjek Penelitian

\begin{tabular}{lc}
\hline Karakteristik & Nilai Statistik $(\mathbf{n}=\mathbf{5 1})$ \\
\hline Usia (tahun) & $65(56-69)$ \\
Laki-laki, \% & 75 \\
Indeks massa tubuh $\left(\mathrm{kg} / \mathrm{m}^{2}\right)$ & $25,3(22,8-27,5)$ \\
Hipertensi, \% & 94 \\
Gagal Jantung, \% & 18 \\
Kreatinin Serum (mg/dL) & $1,7(1,35-2,35)$ \\
EKG: LVH, \% & 37 \\
ACE-inhibitor, \% & 18 \\
Angiotensin reseptor blocker, \% & 16 \\
Beta blocker, \% & 20 \\
Calcium channel blocker, \% & 88 \\
Diuretik, \% & 25 \\
GFR (mL/menit) & $34,4(24,87-43,14)$ \\
eGFR (mL/menit per $\left.1,73 \mathrm{~m}^{2}\right)$ & $41,72 \pm 16,42$ \\
QTVI & $0,16 \pm 0,24$ \\
\hline
\end{tabular}

Data ditampilkan dalam rata-rata \pm SB atau median (rentang) atau persentase

Tabel 2 Distribusi Nilai QTVI, GFR, dan eGFR Subjek Penelitian

\begin{tabular}{ccc}
\hline Variabel & $\mathbf{p}$ & Distribusi \\
\hline QTVI & 0,167 & Normal \\
GFR & 0,020 & Tidak normal \\
eGFR & 0,200 & Normal \\
\hline
\end{tabular}

yaitu 70 subjek penderita penyakit ginjal kronik predialisis di poliklinik Ginjal Hipertensi RS Dr. Hasan Sadikin Bandung. Johansson dkk. ${ }^{11}$ mendapatkan prevalensi hipertensi sebesar $91 \%$ pada penelitiannya.

Penelitian ini mendapatkan nilai QTVI ratarata $0,16(\mathrm{SB} 0,24)$, lebih panjang dibandingkan dengan QTVI rata-rata pada subjek penderita PGK yang dilaporkan oleh Johansson dkk. ${ }^{11}$ yaitu $-0,82$ (SD 0,56). Perbedaan ini mungkin terjadi baik karena mempunyai perbedaan karakteristik populasi subjek penelitian maupun cara dalam melakukan pengukuran. Perbedaan karakteristik populasi tersebut antara lain subjek dengan hipertrofi ventrikel kiri dan gagal jantung, serta penggunaan obat penyekat beta. Pada penelitian ini subjek dengan gambaran hipertrofi ventrikel kiri pada EKG sebanyak 37\%, sedangkan pada penelitian Johansson dkk. ${ }^{11}$ hanya sebanyak $17 \%$. Penelitian sebelumnya telah dibuktikan hubungan positif antara hipertrofi ventrikel kiri dengan QTVI. ${ }^{13}$ Subjek dengan gagal jantung pada penelitian ini lebih banyak dibandingkan dengan penelitian Johansson dkk. ${ }^{11}(18 \%$ vs $7 \%$ ). Berger dkk. ${ }^{14}$ sudah menunjukkan bahwa nilai QTVI pada penderita gagal jantung lebih panjang secara bermakna dibandingkan dengan kontrol. Subjek yang mendapat terapi golongan penyekat beta pada penelitian ini pun jauh lebih sedikit dibandingkan dengan pada penelitian Johansson dkk. ${ }^{11}$ (20\% vs 59\%). Penggunaan obat antihipertensi mungkin memengaruhi nilai QTVI dalam penelitian ini. Penelitian Piccirillo dkk. ${ }^{15}$ menunjukkan perbaikan nilai QTVI pada subjek gagal jantung setelah pengobatan selama satu tahun mempergunakan penyekat beta, meskipun pada subanalisis penelitian Johansson dkk. ${ }^{11}$ tidak didapatkan perbedaan nilai QTVI pada penderita PGK yang mendapat pengobatan penyekat beta dan yang tidak mendapat penyekat beta, begitu

Tabel 3 Korelasi antara QTVI dengan GFR dan eGFR

\begin{tabular}{ccc}
\hline \multirow{2}{*}{ Korelasi } & \multicolumn{2}{c}{ BBLR } \\
\cline { 2 - 3 } & $\mathbf{r}$ & $\mathbf{p}$ \\
\hline GFR & $-0,816$ & $<0,001$ \\
eGFR & $-0,460$ & $<0,001$ \\
\hline
\end{tabular}


pula pada penggunaan antihipertensi golongan lain. Pada penelitian ini tidak dilakukan analisis untuk mengetahui efek penggunaan obat-obat antihipertensi terhadap nilai QTVI karena ukuran sampel yang terlalu kecil.

Perbedaan lain penelitian ini dengan penelitian Johansson yaitu cara melakukan pengukuran. Johansson dkk. ${ }^{11}$ melakukan pengukuran dengan metode automatis menggunakan komputer dan piranti lunak, sehingga memberikan hasil yang kurang bergantung pada operator. Pada penelitian ini, pengukuran dilakukan secara manual karena tidak tersedianya piranti lunak tersebut dan hanya dilakukan oleh satu orang pengamat sehingga perbedaan inter- dan intra-examiner tidak dapat dinilai dan menjadi salah satu kelemahan dalam penelitian ini.

Hasil uji korelasi QTVI dengan laju filtrasi glomerulus menunjukkan hubungan bermakna baik antara QTVI dan GFR ( $\mathrm{r}=-0,816$; $\mathrm{p}<0,001)$ maupun antara QTVI dan eGFR ( $\mathrm{r}=-0,460$; $\mathrm{p}<0,001$ ), namun hubungan antara QTVI dan GFR lebih baik bila dibandingkan dengan antara QTVI dan eGFR. Semakin rendah laju filtrasi glomerulus, makin panjang nilai QTVI. Hasil penelitian ini memberikan informasi yang penting sebab instabilitas repolarisasi miokardium yang diwakili QTVI, merupakan faktor predisposisi terjadi aritmia ventrikel dan kematian mendadak yang sering terjadi pada penderita penyakit ginjal kronik. Studi yang membuktikan nilai prognosis QTVI untuk terjadi aritmia ventrikel dan kematian mendadak masih sedikit, tetapi Atiga dkk. ${ }^{10}$ melaporkan bahwa QTVI dapat memprediksi aritmia ventrikel dan kematian secara mendadak pada penderita yang dilakukan pemeriksaan elektrofisiologi. Penderita dengan QTVI lebih dari 0,1 mempunyai risiko lebih tinggi untuk terjadi aritmia ventrikel dan kematian mendadak. Pada penderita dengan GFR $>60 \mathrm{~mL} /$ menit/1,73 m², kejadian kardiovaskular umumnya disebabkan oleh proses aterosklerosis, ${ }^{2}$ akan tetapi bila GFR turun hingga $<30 \mathrm{~mL} /$ menit/1,73 $\mathrm{m}^{2}$, timbul berbagai kelainan kardiovaskular lain yaitu kalsifikasi dan kekakuan pembuluh darah, gangguan struktur jantung, serta peningkatan aktivitas saraf simpatis yang dapat meningkatkan risiko aritmia jantung dan gagal jantung. ${ }^{3}$ Pada penelitian ini semua subjek dengan GFR $<30 \mathrm{~mL} /$ menit mempunyai QTVI $>0,1$.

Mekanisme yang mendasari pemanjangan QT variability masih terus dipelajari hingga saat ini. Banyak faktor yang terlibat di dalam pengaturan proses repolarisasi miokardium dan interaksi faktor-faktor tersebut sangat kompleks serta belum sepenuhnya dimengerti. Bukti-bukti tersebut telah menunjukkan bahwa instabilitas repolarisasi temporal terjadi mulai dari tingkat sebuah sel, selain itu telah diajukan pula teori seperti perubahan arus repolarisasi, abnormal intracellular ionic cycling, dan perubahan intercelular coupling yang dicetuskan oleh suatu penyakit. ${ }^{16}$ Perubahan dari struktur ventrikel kiri seperti dilatasi dan parut pada kardiomiopati iskemik atau dilatasi, atau hipertrofi ventrikel kiri pada hipertensi yang berhubungan dengan pemanjangan QTVI. ${ }^{13}$ Oleh karena itu, terdapat kelainan kardiovaskular pada penderita PGK seperti hipertensi (lebih dari 90\% subjek penelitian ini), diabetes melitus, penyakit jantung koroner, dan gagal jantung dapat mencetuskan perubahan struktur miokardium yang mungkin mampu menjelaskan pemanjangan QTVI. Pada penderita PGK predialisis, prevalensi LVH meningkat dengan semakin menurunnya GFR, dan LVH terjadi pada hampir $75 \%$ penderita yang mulai menjalani terapi dialisis. Progresivitas hipertrofi sebagiannya dapat dijelaskan oleh hipertensi, akan tetapi faktor risiko potensial lain seperti anemia moderat tidak boleh dikesampingkan. ${ }^{6}$ Pada penelitian ini, sayangnya tidak dilakukan pemeriksaan ekokardiografi dan hal ini juga menjadi kekurangan dalam penelitian ini.

Hasil penelitian ini mendukung laporan sebelumnya bahwa risiko aritmia ventrikel dan kematian mendadak semakin besar seiring makin menurunnya GFR dan penderita dengan GFR $<30$ $\mathrm{mL} / \mathrm{menit}$ merupakan kelompok berisiko tinggi. Pemanjangan QTVI mungkin menjadi salah satu mekanisme yang mendasari hal tersebut, meskipun penelitian QTVI ini masih harus dikembangkan standar metodologinya, serta kemampuan reproduksi hasil dan stabilitasnya masih perlu dipelajari dan diperbaiki.

Nilai eGFR rata-rata subjek penelitian ini sebesar 41,72 mL/menit/1,73 $\mathrm{m}^{2}$. Pada penelitian ini didapatkan hubungan positif yang cukup kuat dan bermakna antara eGFR dan GFR ( $r=0,585$; $\mathrm{p}<0,001)$, sedangkan pada penelitian yang telah dilakukan oleh Modification of Diet in Renal Disease (MDRD) terhadap 1.628 subjek didapatkan hubungan yang sangat kuat antara eGFR dan GFR $(\mathrm{r}=0,90) .{ }^{17}$

Nilai eGFR subjek penelitian didapat berdasarkan rumus dari MDRD. Rumus ini telah diteliti pada lebih dari 50 studi yang meliputi lebih dari 16.000 subjek dan dinilai cukup akurat, akan tetapi rumus MDRD ini memiliki beberapa keterbatasan. Kreatinin serum biasanya diukur menggunakan Jaffe-based methods dan umumnya menghasilkan nilai yang lebih tinggi dibandingkan dengan nilai yang sebenarnya. Hal ini dapat berdampak cukup besar bila kadar kreatinin serum rendah yang justru menjadi perhatian utama saat berpikir untuk menghitung eGFR pada penyakit ginjal kronik stadium 
awal. Penderita dengan massa otot yang rendah (misalnya perempuan) memiliki kadar kreatinin yang lebih rendah dan akan mendapat dampak yang lebih besar dalam masalah ini. Penggunaan referensi yang baku atau penyesuaian alat uji dengan laboratorium MDRD dapat mengurangi masalah ini, akan tetapi meskipun hal tersebut dilakukan, nilai prediksi rumus MDRD tetap kurang akurat dan dapat menjadi makin negatif sehingga menghasilkan nilai prediksi rendah pada GFR yang tinggi terutama $\geq 60 \mathrm{~mL} / \mathrm{menit} /$ $1,73 \mathrm{~m}^{2}{ }^{18}$ Hal ini juga ditunjukkan oleh Stevens dkk. ${ }^{19}$ dalam satu studi metaanalisis yang meliputi 5.504 penderita. Rumus MDRD juga kurang akurat bila diterapkan pada berbagai populasi dengan etnis yang berbeda atau populasi di luar Amerika Serikat, yang mungkin disebabkan oleh perbedaan massa tubuh dan diet. Penderita PGK etnis Cina, rumus MDRD cenderung memberikan nilai prediksi lebih tinggi sebesar $11-12 \mathrm{~mL} /$ menit/1,73 $\mathrm{m}^{2}$ sehingga membutuhkan faktor koreksi tambahan, sedangkan pada etnis IndoAsian belum ada studi hingga saat ini. ${ }^{18}$

Simpulan, terdapat hubungan sangat kuat antara QTVI dan laju filtrasi glomerulus pada penderita penyakit ginjal kronik pradialisis. Makin rendah laju filtrasi glomerulus, makin panjang nilai QTVI.

\section{Daftar Pustaka}

1. Schiffrin EL, Lipman ML, Mann JF. Chronic kidney disease: effects on the cardiovascular system. Circulation. 2007;116(1):85-97.

2. Foley RN, Murray AM, Li S, Herzog CA, McBean AM, Eggers PW, dkk. Chronic kidney disease and the risk for cardiovascular disease, renal replacement, and death in the United States Medicare population, 1998 to 1999. J Am Soc Nephrol. 2005;16(2):48995.

3. Tonelli M, Isles $\mathrm{C}$, Curhan GC, Tonkin A, Pfeffer MA, Shepherd J, dkk. Effect of pravastatin on cardiovascular events in people with chronic kidney disease. Circulation. 2004;110(12):1557-63.

4. Pun PH, Smarz TR, Honeycutt EF, Shaw LK, Al-Khatib SM, Middleton JP. Chronic kidney disease is associated with increased risk of sudden cardiac death among patients with coronary artery disease. Kidney Int. 2009;76(6):652-8.

5. Herzog CA. Cardiac arrest in dialysis patients: approaches to alter an abysmal outcome. Kidney Int Suppl. 2003;63(84):S197-200.

6. Shamseddin MK, Parfrey PS. Sudden cardiac death in chronic kidney disease: epidemiology and prevention. Nat Rev Nephrol. 2011;7(3):145-54.

7. Huikuri HV, Castellanos A, Myerburg RJ. Sudden death due to cardiac arrhythmias. N Engl J Med. 2001;345(20):1473-81.

8. Berger RD. QT variability. J Electrocardiol. 2003;36(Supp1 1):83-7.

9. Piccirillo G, Magrı D, Matera S, Magnanti M, Torrini A, Pasquazzi E, dkk. QT variability strongly predicts sudden cardiac death in asymptomatic subjects with mild or moderate left ventricular systolic dysfunction: a prospective study. Eur Heart J. 2007;28(11):1344-50.

10. Atiga WL, Calkins $\mathrm{H}$, Lawrence JH, Tomaselli GF, Smith JM, Berger RD. Beat-tobeat repolarization lability identifies patients at risk for sudden cardiac death. J Cardiovasc Electrophysiol. 1998;9(9):899-908.

11. Johansson M, Gao SA, Friberg P, Annerstedt M, Bergstrom G, Carlstrom J, dkk. Elevated temporal QT variability index in patients with chronic renal failure. Clin Sci (Lond). 2004;107(6):583-8.

12. Arinanda IGP. Korelasi antara tingkat albuminuria dan tingkat proteinuria dengan hipertrofi ventrikel kiri pada pasien penyakit ginjal kronis predialisis [tesis]. Bandung: Universitas Padjadjaran; 2011.

13. Piccirillo G, Germano G, Quaglione R, Nocco M, Lintas F, Lionetti M, dkk. QT-interval variability and autonomic control in hypertensive subjects with left ventricular hypertrophy. Clin Sci (Lond). 2002;102(3):363-71.

14. Berger RD, Kasper EK, Baughman KL, Marban E, Calkins H, Tomaselli GF. Beat-tobeat QT interval variability: novel evidence for repolarization lability in ischemic and nonischemic dilated cardiomyopathy. Circulation. 1997;96(5):1557-65.

15. Piccirillo G, Quaglione R, Nocco M, Naso C, Moise A, Lionetti M, dkk. Effects of long-term beta blocker (metoprolol or carvedilol) therapy on QT variability in subjects with chronic heart failure secondary to ischemic cardiomyopathy. Am J Cardiol. 2002;90(10):1113-7.

16. Walker ML, Rosenbaum DS. Repolarization alternans: implications for the mechanism and prevention of sudden cardiac death. Cardiovasc Resc. 2003;57(3):599-614.

17. Poggio ED, Wang X, Greene T, Van Lente F, Hall PM. Performance of the modification of diet in renal disease and Cockcroft-Gault equations in the estimation of GFR in health and in chronic kidney disease. J Am Soc Nephrol. 2005;16(2):459-66. 
Sugiantoro: Hubungan antara QT Variability Index dan Laju Filtrasi Glomerulus pada Penderita Penyakit Ginjal Kronik

18. MacGregor MS. How common is early chronic kidney disease? A background paper prepared for the UK Consensus Conference on early chronic kidney disease. Nephrol Dial Transplant. 2007;22(Suppl 9):ix8-18.

19. Stevens LA, Coresh J, Feldman HI, Greene
T, Lash JP, Nelson RG, dkk. Evaluation of the modification of diet in renal disease study equation in a large diverse population. J Am Soc Nephrol. 2007;18(10):2749-57. 